\title{
Educational reform in Turkey
}

\author{
Necmi Aksit \\ Graduate School of Education, Main Campus, G-267, Bilkent University, 06800 Ankara, Turkey
}

\begin{abstract}
There are a number of reform initiatives underway in Turkey but some of these, which are concerned with curricular and structural changes, have encountered serious difficulties. This paper begins with a brief summary of school effectiveness and school improvement research guiding many educational reforms. It then gives some information about school demographics in Turkey, and the country's performance in some international benchmarking studies. It continues with the shifts introduced as a result of recent curricular reorganisation in Turkey and, subsequently, with various issues related to their implications. Finally, the efforts to legislate some structural changes and the major controversies arising are presented.
\end{abstract}

(C) 2006 Published by Elsevier Ltd.

Keywords: Educational reform; Curriculum; Educational policy; School effectiveness; School improvement; Comparative education

\section{Introduction}

Educational reform efforts in Turkey have been somewhat piecemeal, and have not generally touched core educational practices. Although various superficial modifications have been made in the past, most have not had the substantial effect hoped for. Fragmented changes were made, usually to gain political advantage, but the basic systems to a large extent stayed the same.

Education is a right but it is a costly one, and it becomes more expensive when educational policies no longer address present concerns. To meet the challenges of today's classroom and society, it is essential that educational systems are evaluated on a regular basis, and that informed policy decisions are made based on research into processes and outcomes of schooling.

E-mail address: necmi@bilkent.edu.tr.

\subsection{School effectiveness and school improvement}

Educational reform movements in general are intended to improve education and schools, and to make them more effective. Since the 1980s, the concepts of school effectiveness and school improvement have gained growing popularity. The outcomes of related research studies have significantly contributed to reform movements in many areas of education from curriculum to assessment, and instruction to leadership.

School effectiveness is concerned with the outcomes of schooling (Harris and Bennett, 2005). The history of school effectiveness literature goes back to the mid-1960s when Coleman et al. (1966) presented the controversial argument that only a small proportion of variation in student achievement can be accounted for by variation in schools when compared with other factors such as family background. However, the findings of two studies conducted in the late 1970s (Edmonds, 1979; Rutter 
et al., 1979) concluded that schools make a small but highly significant difference. Subsequent research confirmed the finding that schools differ significantly from each other with regard to their effects on student achievement (Sammons et al., 1997). The literature (OECD, 1998, p. 13) suggests that "school factors account for, at most, some 25 per cent of the variance in student performance".

The debate about the effect of the school led to the identification of some school characteristics that help to make a difference: academic goals, high expectations, meaningful student responsibility and participation, frequent monitoring of student progress, community support and involvement are some important ones (Lunenburg and Ornstein, 1996). Research into effective schools continues to gain interest due to its contribution to reform movements mainly in the areas of data-driven assessment, structural and cultural change and teacher effectiveness (Griffith, 2002; Harris and Bennett, 2005). However, the growth in knowledge has produced "as many unanswered questions as questions answered" (Reynolds, 1993, p. 2).

Whereas school effectiveness is more concerned with the outcomes of schooling, school improvement focuses on the processes of schooling and considers various contextual factors such as day-today academic decisions or curriculum implementation (Harris and Bennett, 2005). School improvement efforts are initiated mostly at the school level, using multiple measures to identify different outcomes, and seeking to give the ownership of the development to the immediate stakeholders (Sammons et al., 1997).

Research on school improvement suggests there are a number of key variables any effort should take into consideration. Expecting high achievement for all students, increasing student motivation, providing focused and sustained professional development, seeking strong parental involvement, and decision-making at the school level could be listed among such variables (Hopkins and Levin, 2000; Hoachlander et al., 2001).

School improvement with a view to personalising educational experience has also led to the development of a comprehensive high school reform programme, and school reform models in the US (OVAE, 2006). For example, Accelerated Schools $P L U S$ aims to help all students "excel to high levels, regardless of their background", offering a minimum 5 year partnership with the schools interested (AS Plus, 2006). Co-nect offers another model that many schools in 35 states in the US have partnered with. This model believes that improvement comes through the teacher, and therefore focuses on "improving the quality of instruction" through "a customised professional development plan" (Co-nect, 2006). The ATLAS Communities' model is designed to "help create high performing schools," focusing on five key elements for improving student achievement: teaching and learning; assessment; professional development; family and community; and management and decision-making (ATLAS, 2006).

\subsection{Measuring educational impact}

How can effectiveness or improvement be measured? What counts as evidence? In different parts of the world, there are different practices. Countries like the US and the UK have established policies that centre on outcomes-based education, standards and accountability systems on the basis of test scores. In the UK, for example, the annual league table system ranks schools on the basis of examination results. The ATLAS communities in the US use school report cards for demonstrable improvements in the form of, for example, percentage of students meeting or exceeding state standards in maths, English, science and history (ATLAS, 2006). Also some states like Tennessee use value-added assessment modelling (VAM) to measure the impact of instruction on student learning (Sanders, 1998).

As for the European Union (EU, 2006), member countries have agreed on 16 indicators for the quality of school education to facilitate the evaluation of education systems at national level, and to help identify common issues that need to be examined. The quality indicators are concerned with attainment in the areas of mathematics, reading, science, information and communication technology (ICT); success and completion of upper secondary education; monitoring of school education by various stakeholders; and resources, training for teachers and infrastructure. One of the major challenges identified, however, is the availability of data for each indicator and data comparability (European Commission, 2005).

It is the responsibility of each EU member country to pursue the strategic objectives of the Union in order to establish quality education systems by 2010. It is also imperative for EU candidate countries to assess the state of their education system with a view to making operational 
decisions to achieve the strategic ends of the Union. In 2006, there are four countries with official candidate country status. Bulgaria and Romania successfully completed the accession negotiations and will join the Union as member states in January 2007. Two others, Turkey and Croatia, have opened accession negotiations: Turkey in October 2005, and Croatia in March 2005.

Turkey fulfilled the Copenhagen criteria in 2004 and the European Commission adopted a framework for accession negotiations in 2005. The first phase of the negotiations is called screening: its main purpose is to assess the degree of preparedness to take on the obligations of membership and the administrative capacity to apply and implement the acquis of the Union. In Turkey's case, the acquis consists of 35 chapters. Each covers a policy area. The information obtained during screening will be used for laying down benchmarks chapter by chapter during the negotiation phase to bring the candidate country into line with the standards accepted and implemented by EU member countries. The whole process of screening in Turkey began in November 2005 with Chapter 26: Education and culture. The focus is on the areas of education, training, youth and culture (European Commission, 2005).

\subsection{Education in Turkey}

Turkey has a population of 72 million, estimated to rise to about 82 million by 2015 . There are some 13 million students at the formal primary and secondary education levels with more than 500,000 teachers (MONE, 2001).

Formal education in Turkey may be preceded by a non-compulsory pre-school year. Currently the pre-school education schooling rate is $16 \%$ (OÖEGM, 2005), and the objective of the Ministry of National Education (MONE) is to increase the rate to $25 \%$ by 2010 .

Compulsory education was increased from 5 to 8 years in 1997. There are now more than ten million children receiving 8 years' compulsory primary education in public and private educational institutions with about 375,000 teachers. The gross enrolment ratio at this level is approximately $91.9 \%$ of the relevant age population (UNDP, 2004).

Secondary school is not yet compulsory but was extended from 3 to 4 years from September 2005. Students at this level may choose to go to a general high school, which prepares them for institutions of higher education, or a vocational/technical high school, which provides specialised education. There are some 1.5 million students in general high schools, and 820,000 students in vocational/technical high schools. The combined general and vocational/technical high school enrolment rate is $73.3 \%$ of the age group (UNDP, 2004).

At tertiary level, there are 53 state universities and 19 private universities established by foundations. Entry into tertiary level education is extremely competitive. In 2005, some 1.8 million students sat a national examination for about 400,000 places in tertiary education institutions, including vocational ones and the Open University. The vocational high school graduates, however, may apply to 2-year higher vocational schools without taking the university entrance exam. Institutions of tertiary education, in total, hold some 1.9 million students. The enrolment rate at this level is about $23.8 \%$ (UNDP, 2004).

The gross enrolment rate in Turkey, when primary, secondary and tertiary educations are combined, is $61 \%$. The female ratio is $54 \%$, and the male ratio is $65 \%$ (UNDP, 2004). The adult literacy rate, for people aged 15 and over, is $86.5 \%$, the male and female rates being $94.4 \%$ and $78.5 \%$, respectively (UNDP, 2004).

\subsection{International benchmarks}

Expenditure on education in Turkey is increasing but educational attainment is still among the lowest of the Organisation for Economic Co-operation and Development (OECD) countries. "Raising standards of achievement is seen as fundamental to economic performance" and social change (Sammons, 2006). However, international benchmarking studies such as PISA and PIRLS report low levels of attainment as far as Turkey is concerned. Attainment in the areas of mathematics, reading and science is included in the 16 indicators on the quality of school education (European Commission, 2005).

\subsection{The Programme for International Student Assessment (PISA)}

PISA is an internationally standardised benchmarking assessment tool that was developed by participating countries (OECD, 2004). It focuses on how well young people, 15-year-olds, are able to use their knowledge and skills to meet the challenges of 
real-life rather than how well they have mastered a specific school curriculum (OECD, 2004). It allows for the monitoring of the outcomes of education systems within an internationally accepted common framework.

In 2003, the PISA was administered in 41 countries. It had four sections, namely mathematics, reading, science and problem solving, and the main emphasis was on mathematical literacy. The results of this assessment show that Turkey's mean combined public and private school performance in the mathematics section was 423 , in a range of 356-550, and significantly lower than the average of OECD countries. In mathematics, $51 \%$ of the students from Turkey were at the lowest level 1 or below, out of six levels (OECD, 2004) (Fig. 1). Level 1 meant students "are able to identify information and carry out routine procedures according to direct instructions in explicit contexts" (OECD, 2004, p. 47).

When the performance of private and public schools is analysed separately, however, the results vary significantly in favour of the private schools in Turkey (Table 1). In each of the four areas, the performance of private schools is higher than both the performance of public schools in Turkey, and the average OECD public and private school performance.

\subsection{The Progress in International Reading Literacy Study (PIRLS)}

The results of another study, called PIRLS, were not much different from those of the PISA. The PIRLS provides information about the reading achievement of primary school students, concentrating on fourth grade students (Fig. 2). In this study, Turkey's average of 449 was significantly lower than the international average 500 , in a range 327-561, and was below the average of most countries (PIRLS, 2001).

\subsection{Recent educational reform in Turkey}

To upgrade educational provision, Turkey had made some alterations in the education system long before it was accepted in December 2004 as an EU candidate country. To meet the strategic educational objectives of the EU, some reforms are underway, some are on the horizon, and more will come once the screening process with the EU related to the Chapter 26 of the acquis is completed.

Two reform initiatives in particular have captured the attention of various stakeholders. One is curricular: it was launched in 2005, and the aim was to make major alterations in the educational

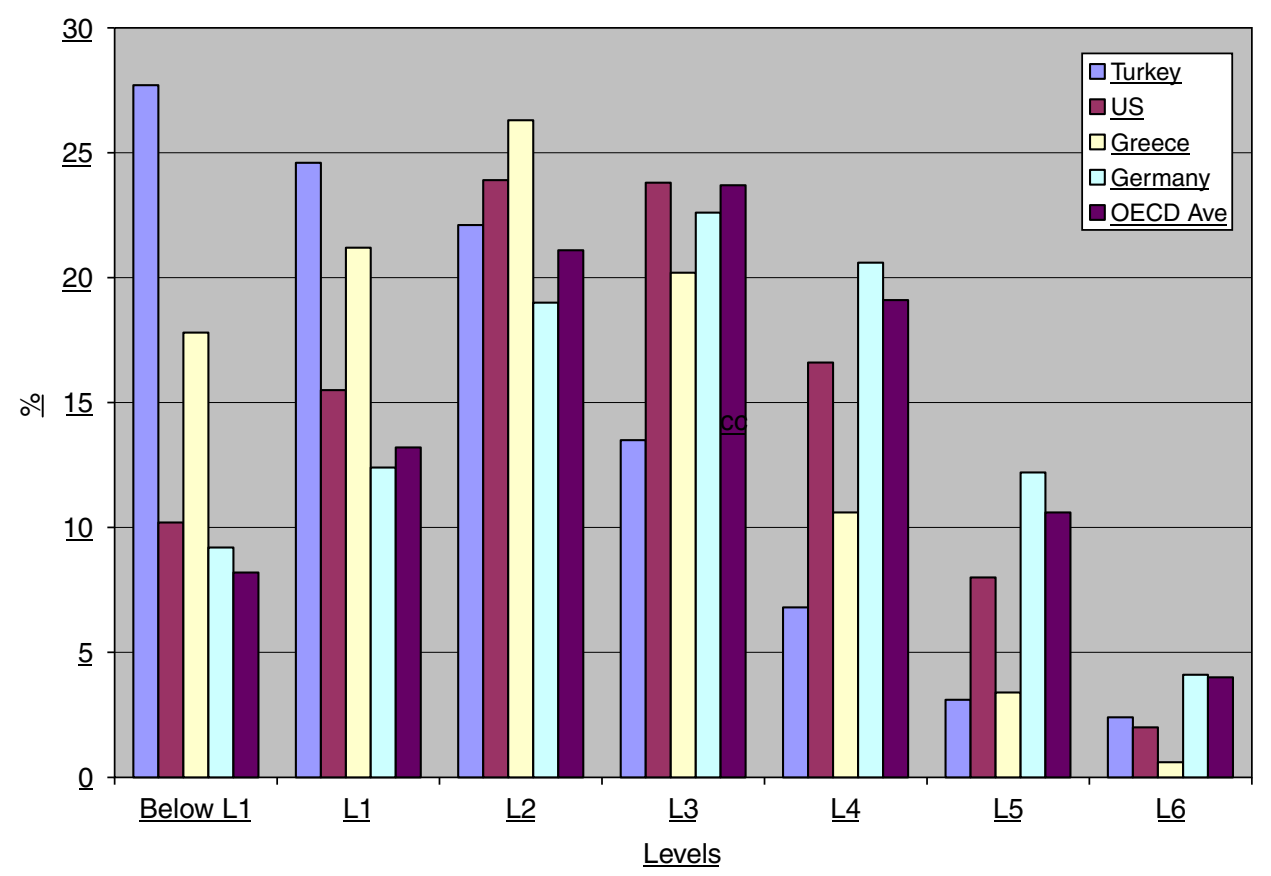

Fig. 1. PISA-percentage of students (from selected countries) at each level of proficiency on the mathematics scale: the results of Programme for International Student Assessment (PISA) on the mathematical scale. 
Table 1

Public and private school performance in PISA 2003

\begin{tabular}{llllll}
\hline Country & School type & Reading (Mean) & Maths (Mean) & Science (Mean) & Problem solving (Mean) \\
\hline Turkey & Public & 437 & 418 & 430 & 403 \\
OECD Average & Public & 488 & 493 & 494 & 493 \\
Turkey & Private & 557 & 569 & 563 & 536 \\
OECD Average & Private & 517 & 526 & 521 & 524 \\
\hline
\end{tabular}

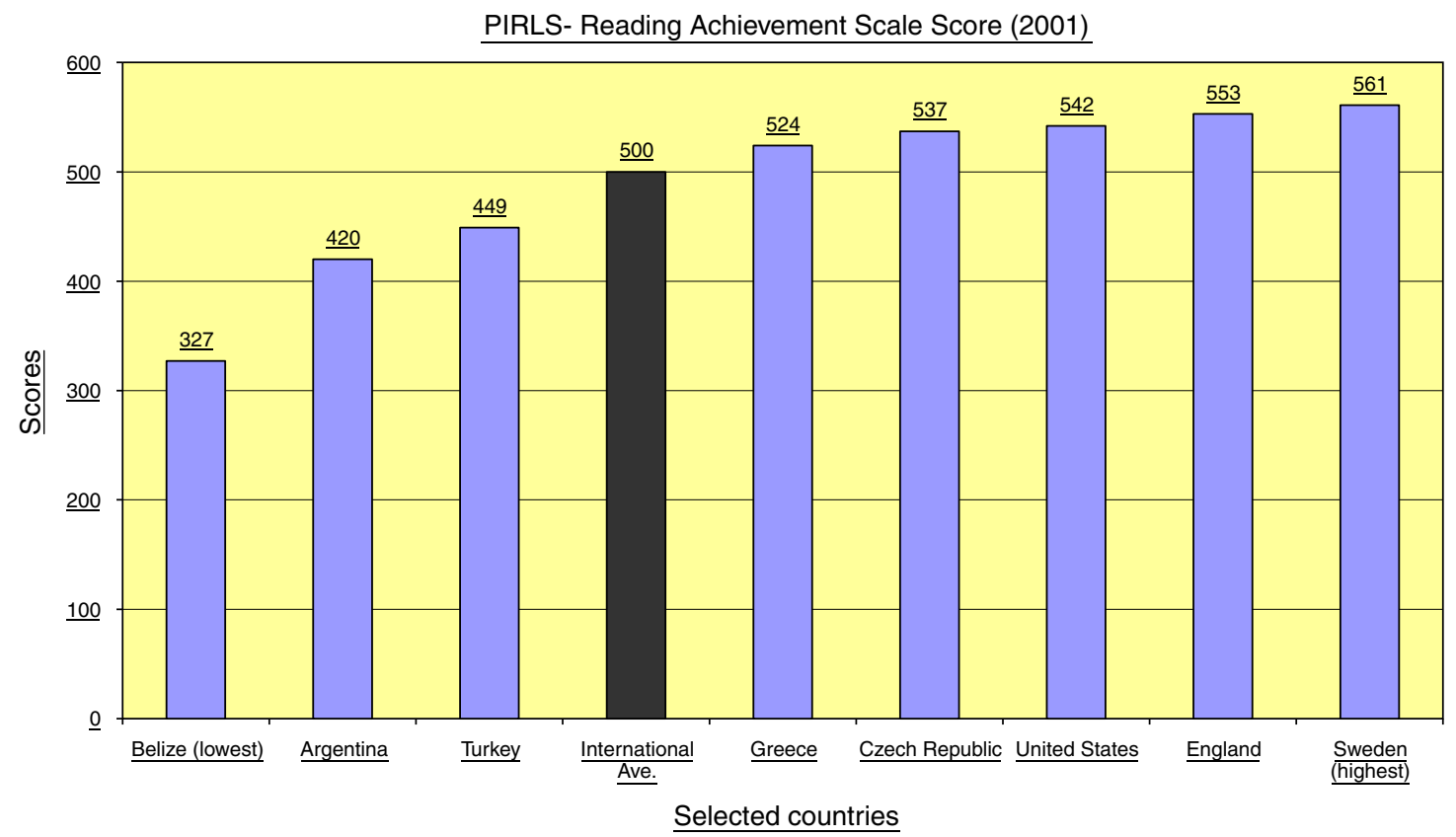

Fig. 2. PIRLS-reading achievement scale score: the results of Progress in International Reading Literacy Study-PIRLS on the reading achievement of 4 th grade primary school students.

system with a view to preparing young citizens better for the real world. The other reform is structural, with one of its main objectives being to decentralise educational provision in Turkey. It did not succeed when it was first introduced in 2004, but it is still being reconsidered.

\subsection{Curricular reform}

The purpose of the curriculum reform of 2005 is to change considerably the focus and content of the whole national curriculum in three phases. The first phase is to develop and pilot a new curriculum for grades $1-5$, mainly in the areas of science, social science, mathematics and Turkish. This curriculum was developed and piloted in 120 schools in nine cities in 2004-2005. It was then revised and implemented nation-wide from September 2005. The second phase, which intends to develop a new curriculum for grades 6-8, is still being developed. The third phase is to design a new curriculum for the new 4-year high school, the ninth grade of which is a common year for general and vocational high school students (Talim Terbiye Kurulu, 2004, 2005).

The main objectives of the curriculum reform are (Talim Terbiye Kurulu, 2005):

- to reduce the amount of content and number of concepts

- to arrange the units thematically

- to develop nine core competencies across the curriculum

- to move from a teacher-centred didactic model to a student-centred constructivist model

- to incorporate ICT into instruction

- to monitor student progress through formative assessment 
- to move away from traditional assessment of recall, and introduce authentic assessment

- to enhance citizenship education

- to introduce second language courses from primary school

- to widen the scope of religious education

- to establish a system of student representation, and engage students in community work

To guide teachers in new patterns of teaching, the MONE has also redefined teacher competencies. Different from previous approaches, the Ministry has draughted two sets of competencies: core competencies across disciplines, and subject areaspecific competencies. The core competencies include considering students' needs, interests and wants, the process of teaching and learning, monitoring progress, and relationships with parents and community. To support the direction of philosophical change, these core competencies implicitly suggest that teachers are not only responsible for the personal and academic development of students but also for establishing a democratic social environment, and promoting tolerance and diversity (ÖYEGM, 2003).

\subsection{Major controversies-I}

Although many external and internal stakeholders are concerned about the new approach to curriculum development, much of the current controversy is not about the direction of the curriculum reform but about how to get there in the fastest and most efficient way.

With regard to the process of curriculum development for grades 1-5, the feeling expressed by faculties of education, and some NGOs including the education union, is that it was rushed and was not discussed in a wider context at sufficient length. Although the MONE stated that students, teachers, inspectors, parents, academics and NGOs were consulted during the process, the faculties of education regretted that they were not formally involved, and therefore could not make their contribution to the development of the new curriculum (HEC, MONE, 2006).

Another criticism was that the outcomes of the piloting process, including teacher and student feedback, and the modifications made based on the feedback, were never reported and discussed in an open forum. Instead, the schools were sent textbooks for the new curriculum, and asked to use them right away (HEC, MONE, 2006).

Faculties of education saw that this was a massive educational renewal process, requiring academic staff at the faculties of education, and approximately 400,000 teachers in primary education to make fundamental shifts in their views in order to adapt to and accommodate the changes. They were concerned with the lack of information available at the beginning. They would have wished to incorporate the changes into their pre-service teacher education courses, and help in-service teachers. To implement the new curriculum as intended and to facilitate teacher adoption, they considered it essential to provide the pre-service training institutions, as well as practising teachers with time to discuss, evaluate, interpret and understand the new content, objectives, teaching strategies including ICT and assessment types (HEC, MONE, 2006). In their view, this did not happen.

From 2005, the new 1-5 curriculum was implemented nationwide. Prior to full implementation, five-day training-the-trainers workshops were held mainly for experienced teachers who would then cascade their training. Following the initial training, a concern voiced widely by the universities and some NGOs is that teachers will continue to need effective ongoing professional support at the school level: most teachers use the transmission model of teacher-centered methods and have not been trained in a constructivist way of teaching (HEC, MONE, 2006; Istanbul Politikalar Merkezi, 2005; EğitimSen, 2005). It would, therefore, be quite a challenge for them to set authentic tasks to involve students in the teaching-learning process. The faculties of education believe that they have a role to play, and should be actively involved in accelerating the rate of diffusion of innovation.

To ensure sustained improvements, the faculties of education also suggest that a mentoring system be instituted to assist teachers in the adoption of the key components of the innovation. Mentors could be trained by the universities to demonstrate constructivist methodology and how to use constructivist methods; how to incorporate formative assessment and ICT into instruction; how to develop authentic assessment; and how to support citizenship education across the curriculum, and through classroom management strategies (HEC, MONE, 2006; Istanbul Politikalar Merkezi, 2005; Eğitim-Sen, 2005).

While how to integrate ICT into instruction is already a major concern for the faculties of education, 
many stakeholders are more worried about the availability of essential resources that facilitate the implementation of the new curriculum. It is a huge undertaking, requiring sustainable infrastructure. Students and teachers need to have knowledge and skills to use it effectively. There has already been considerable investment in school infrastructure, internet access, computers and computer labs and multimedia resources. However, various resources needed to implement lessons as intended, including overhead projectors and photocopy machines, are lacking in many schools (Istanbul Politikalar Merkezi, 2005; Eğitim-Sen, 2005).

How about parents? The perceptions of the parents during the piloting of the new curriculum were not publicised, and there is no other data available reflecting their views during its implementation. Parents in Turkey are usually very concerned with their children's success in the national examinations which control entry to a relatively few quality educational institutions at high school level and tertiary level. In the past, these examinations have interfered with the effective implementation of the curriculum, as parents wanted their children to attend private intensive coaching establishments called dersanes to prepare them for the examinations. The response of parents to the new curriculum is yet to be seen, but it is possible that it will be based on its usefulness in helping their children to be successful in national examinations.

\subsection{Structural reform}

Educational reform initiatives in Turkey are not only curricular but also structural. A structural reform was introduced in 2004, intending to redefine the central role of the Ministry of National Education, and to reallocate roles and responsibilities accordingly. However, the suggested changes resulted in major controversy and they still await solution. There are currently three issues on the agenda: decentralising primary and secondary education by devolving the power of the central authority to local authorities; making local authorities become responsible for personnel management; and changing the role of the Higher Education Council (HEC).

\subsection{Major controversies-II}

Turkey has the most highly centralised educational system of any OECD member state (Fretwell and Wheeler, 2001). Education in schools is centrally governed by the MONE. The Ministry makes all policy decisions, arranges all aspects of the formal curriculum, and controls implementation with the help of provincial offices.

Initially, in 2004, a public administration reform devolving decision-making power from central authorities was ratified by parliament. The implications of the reform included decentralisation of education, allowing local authorities to make policy decisions, and enabling them to delegate their responsibility to universities, private sector or other non-governmental organisations. However, universities, the HEC, some NGOs and most political parties were very much concerned with the impact this would make on the state's mission to provide equal educational opportunities. They said that there was already significant inequality in income share in Turkey, resulting in migration to western parts of the country (UNDP, 2003). Such a decentralisation model would exacerbate the current situation, resulting in greater disparity. It was also argued that this was against the guiding principles of the Basic Law on National Education, which emphasises equal access and equal right to education. Additionally, they were concerned that this model would eventually result in abolishing the principle of unification of education: students would no longer have equal access to a common curriculum or achieve similar levels of competency. The controversy does not end there. They also pointed out that such a model would make education provision increasingly politicised, allowing local education authorities to gain political advantage.

One of the main responsibilities of the state, then, is to provide equal educational opportunities to all, and this cannot be completely delegated to governmental or non-governmental local authorities, including the private sector. Thus, instead of decentralising education, it is argued that it would be more functional to empower local authorities to make local decisions about educational provision within the framework of a unified system.

Another area of controversy caused by the structural reform is about changing the tenure status of educational staff, and allowing local authorities to make all personnel decisions from recruitment to termination of employment.

Educational staff who work at public schools are employed as civil servants, and have a fairly secure 
position. With the proposed change, however, they would work on a contractual basis. The faculties of education argue that this practice would increase the teacher turnover rate and affect continuity. They also argue that it may lead to hiring and firing of teachers on political grounds rather than on qualifications and experience. Such practice may also call for different standards and teacher certification requirements for different regions. What is needed, according to the faculties, is to continue to have a national policy on performance standards and teacher certification requirements.

Despite criticisms, these structural reforms went through Parliament, but were subsequently vetoed by the President of the Republic on the grounds that they were against the Constitution and endangered the unity of the country. Parliament can overturn the veto by approving the legislation a second time, in which case the President may challenge the legislation by applying to the Constitutional Court.

Yet another area of controversy is about changing the structure and the role and responsibilities, of the HEC, which governs tertiary education in Turkey. The HEC has been functioning outside the political frame since the Constitution of the Republic was changed in 1982. It supervises all universities, both public and private. The Council of Ministers plays a role in adoption of general policies concerning primary and secondary education, and for some time, the Council has also wanted to have a say in matters of tertiary education, and the practices of the HEC.

To this end, the Turkish Parliament passed a higher education law in 2004. However, many political parties, universities, and non-governmental organisations expressed their disagreement with and concerns about the law, stating that political parties in power should not intervene with in higher education, as had happened disastrously prior to the army coup of 1980. They also argued that it would jeopardise the secular ideology of the country. They feared that the real motive behind the law was religious: to change the point system for entry to universities in favour of vocational schools in general, and religious high schools in particular, and to lift the headscarf ban at universities. This was the cause of another veto by the President of the Republic because he thought some articles of the law were not in line with the constitutional principles of secularism and unity of education.

\subsection{Future}

We have seen, then, that many curricular and structural educational reforms are under way in Turkey but some are encountering serious difficulties. With regard to the current curriculum renewal, we see that it is an enormous undertaking that will take years, and possibly decades, to complete, consuming considerable resources. There are more than 500,000 school teachers. They are now required to adopt a totally different methodology. They will have to adapt to the changes when the entire curriculum is redesigned. Educational change of this magnitude requires leadership, collaboration and personal transformation. Above all, it requires provision of sustained support to reduce the potential discrepancy between the intended and the implemented curriculum. Rogers (1995) considered that to further accelerate the direction of a curricular innovation, it is essential that ongoing school-level professional support be given to teachers, and the views of parents, students and teachers be collected on a regular basis.

While the curricular reform has been received positively in general, many aspects of the structural reform have caused heated controversy. The structural changes are still on the agenda, and they will probably regain momentum during and following the EU negotiations. For example, the centralised structure of higher education is one of the items discussed during the accession screening process for Chapter 26 of the acquis: education and culture.

Whether curricular or structural, or whether initiated internally or externally, there is no guarantee that practice follows policy (Hopkins and Levin, 2000). The rate of adoption of any change will not only depend on what the changes are and how they are presented, but also how they are perceived by the main stakeholders. Therefore, it is essential to examine perceptions of the endusers, considering various contextual factors. Otherwise, personal goals, values, concerns and beliefs would go unaddressed, a mistake which would have crucial bearings on the success of the whole endeavour.

\section{References}

AS Plus, 2006. Available from 〈http://www.acceleratedschools.net $>$. Access date: Feb 20, 2006.

ATLAS, 2006. Available from 〈http://www.atlascommunities.org $\rangle$. Access date: 20 February 2006. 
Coleman, J.S., Campbell, E., Hobson, C., McPartland, J., Mood, A., Weinfeld, F., York, R., 1966. Equality of Educational Opportunity. US Government Printing Office, Washinton, DC.

Co-nect, 2006. Available from 〈http://www.co-nect.net/ home.html $\rangle$. Access date: 20 February 2006.

Edmonds, R., 1979. Effective schools for the urban poor. Educational Leadership 37 (10), 15-24.

Eğitim-Sen, 2005. Yeni ilköğretim müfredatının değerlendirilmesi. Available from 〈http://www.egitimsen.org.tr/index.php? yazi $=10>$ Access date: 7 February 2006.

European Commission, 2005. Turkey 2005 progress report. Available from 〈http://europa.eu.int/comm/enlargement/report_2005/ pdf/package/sec_1426_final_en_progress_report_tr.pdf $\rangle$. Access date: 20 February 2006.

EU-European Union, 2006. Summaries of legislation. Available from 〈http://europa.eu.int/scadplus/leg/en/cha/c11063.htm 〉. Access date: 24 February 2006.

Fretwell, D.H., Wheeler, A., 2001. Turkey: Secondary Education and Training. The World Bank, Washington, DC.

Griffith, J., 2002. Is quality/effectiveness an empirically demonstrable school attribute? Statistical aids for determining appropriate levels of analysis. School Effectiveness and School Improvement 13 (1), 91-122.

Harris, A., Bennett, N., 2005. School Effectiveness and School Improvement: Alternative Perspectives. Continuum, London.

HEC, MONE, 2006. The new curriculum. A Joint 3-day Workshop held by the Higher Education Council and the Ministry of National Education for the Faculties of Education, 25-27 January, Ankara.

Hoachlander, G., Alt, M., Beltranena, R., 2000. Leading school improvement: what research says. SREB, Berkeley. Available from <http://www.sreb.org/main/Leadership/pubs/ 01V04_LeadingSchool_Improvement.pdf $\rangle$. Access date: 7 February 2006.

Hopkins, D., Levin, B., 2000. Educational reform and school improvement. NIRA Review, vol. 7, No. 3, Summer. Available from 〈http://www.nira.go.jp/publ/review/ 2000summer/hopkins.pdf $\rangle$. Access date: 7 February 2006.

Istanbul Politikalar Merkezi, 2005. Yeni öğretim programlarını inceleme ve değerlendirme raporu. Unpublished Report.

Lunenburg, F.C., Ornstein, A.C., 1996. Educational Administration: Concepts and Practices, second ed. Wadsworth Publishing Company, Belmont.

MONE, 2001. Turkish education system and developments in education. Forty-sixth Session of the International Conference on Education for All Learning To Live Together: Contents and Learning Strategies-Problems and Solutions.
Available from 〈http://www.ibe.unesco.org/International/ ICE/natrap/Turkey.pdf $\rangle$. Access date: 1 May 2004.

OECD, 1998. Overcoming Failure. OECD, Paris, France.

OECD, 2004. Learning for Tomorrow's World. First Results from PISA 2003. OECD, Paris, France.

OÖEGM-Okul Öncesi Eğitim Genel Müdürlüğü, 2005. Yapılan ve devam eden çalışmalar. Available from <http:// ooegm.meb.gov.tr/faaliyetler.html $\rangle$. Access date: 20 August 2005.

OVAE - Office of Vocational and Adult Education, 2006. High school reform models that support student achievement. Available from <http://www.ed.gov/about/offices/list/ovae/ pi/hs/reform.html $\rangle$. Access date: 8 February 2006.

ÖYEGM-Öğretmen Yetiştirme ve Eğitimi Genel Müdürlüğü, 2003. Öğretmen yeterlilikleri. Available from <http:// oyegm.meb.gov.tr/yet $>$. Access date: 1 July 2005.

PIRLS, 2001. PIRLS 2001 International Report. Availble from 〈http://isc.bc.edu/pirls2001i/PIRLS2001_Pubs_IR.html〉. Access date: 22 August 2005.

Reynolds, D., 1993. School effectiveness and school improvement: an updated review of the British literature. In: Reynolds, D., Cuttance, P. (Eds.), School Effectiveness: Research, Policy and Practice. Cassell, London, pp. 1-24.

Rogers, E.M., 1995. Diffusion of Innovations, fourth ed. Free Press, New York.

Rutter, M., Maughan, B., Mortimore, P., Ouston, J., 1979. Fifteen Thousand Hours: Secondary Schools and Their Effects on Children. Open Books, London.

Sammons, P., 2006. School effectiveness and equity: making connections. Keynote speech made at the International Congress for School Effectiveness and Improvement, Florida.

Sammons, P., Thomas, S., Mortimore, P., 1997. Forging Links: Effective Schools and Effective Departments. Paul Chapman, London.

Sanders, W.L., 1998. Value-added assessment. The School Administrator 55 (11), 24-27.

Talim Terbiye Kurulu, 2004. Program geliştirme çabaları. Available from 〈http://programlar.meb.gov.tr/index/giris_ index.htm $\rangle$. Access date: 15 December 2004.

Talim Terbiye Kurulu, 2005. İlköğretim 1-5. sınıf programları tanıtım el kitabı. MEB, Ankara.

UNDP, 2003. Human development indicators 2003. Availble from 〈http://hdr.undp.org/reports/global/2003/indicator/ index.html $\rangle$. Access date: 20 April 2004.

UNDP, 2004. Country evaluation: Assessment of development results. Turkey. Available from 〈http://www.undp.org.tr $\rangle$. Access date: 18 August 2005. 